\title{
Purification and Characterisation of Xanthine Oxidoreductases from Local Bovids in Malta
}

\author{
Marita Vella1, Therese Hunter ${ }^{1}$, Claude Farrugia'2 ${ }^{\text {, Arwen R. Pearson }}$, \\ Gary Hunter ${ }^{1 *}$ \\ ${ }^{1}$ Department of Physiology and Biochemistry, University of Malta, Msida, Malta \\ ${ }^{2}$ Department of Chemistry, University of Malta, Msida, Malta \\ ${ }^{3}$ Astbury Centre for Structural Molecular Biology, University of Leeds, Leeds, UK \\ Email: "gary.hunter@um.edu.mt
}

Received 10 January 2014; revised 15 February 2014; accepted 1 March 2014

Copyright (C) 2014 by authors and Scientific Research Publishing Inc.

This work is licensed under the Creative Commons Attribution International License (CC BY). http://creativecommons.org/licenses/by/4.0/

(c) (i) Open Access

\begin{abstract}
Xanthine oxidoreductase (XOR) is a molybdoflavoprotein mainly involved in purine catabolism. It exists in two forms, the oxidase (XO) and dehydrogenase (XDH) which are inter-convertible within mammalian cells. Although various researchers have reported the extraction of mammalian XOR, no extractions have yet been carried out in Malta and subsequently no characterizations are available. In this study, XOR was successfully purified from bovine, caprine and ovine milk through a multistep purification process involving both chemical and chromatographic techniques. The molecular weights of the native enzyme were found to be $295 \mathrm{kDa}, 281 \mathrm{kDa}$ and $275 \mathrm{kDa}$, representing the bovine, caprine and ovine XOR respectively. Western blot showed XOR to be represented on SDS-PAGE by a minimum of three major bands having molecular weights of 151 $\mathrm{kDa}, 131 \mathrm{kDa}$ and $85 \mathrm{kDa}$. While all samples showed activity on native PAGE, spectrophotometric assays revealed the bovine XOR to be the most active. Surprisingly, the addition of $\mathrm{NAD}^{+}$to the assay mixture inhibited enzyme activity of the bovine and caprine XOR whereas the ovine XOR doubled its activity in response to $\mathrm{NAD}^{+}$. The latter also showed a lower binding affinity to heparin. Following incubation with trypsin, XOR was irreversibly converted to its oxidase form in all samples as reflected by the observed increase in XO activity.
\end{abstract}

\section{Keywords}

Xanthine; Xanthine Dehydrogenase; Xanthine Oxidase; Milk; Bovid; Malta

\footnotetext{
"Corresponding author.
} 


\section{Introduction}

Xanthine oxidoreductase (XOR) is a molybdenum hydroxylase which is able to oxidize a wide range of heterocyclic molecules including purines, pyridines and pterins [1] [2]. In addition to its well established role in purine catabolism, Vorbach et al. [3] proposed that XOR also contributes to the innate immune system due to the antioxidant properties of uric acid. Recent studies have also identified XOR as an antibacterial agent in milk [4] [5].

XOR exists in two forms, as xanthine dehydrogenase (XDH, EC 1.17.1.4) and xanthine oxidase (XO, EC 1.1.3.22). Although the xanthine dehydrogenase is the most abundant form in vivo [6], in mammalian cells it interconverts to the oxidase form either through oxidation of the thiol groups (reversible) or proteolytic cleavage (irreversible) [1]. XO and XDH mainly differ in the structure of the flavin adenine dinucleotide (FAD) domain which affects their choice of electron acceptors. Eukaryotic XOR is a dimeric enzyme made up of two identical subunits each acting autonomously. The monomer is composed of three interlinked domains which constitute an electron transfer pathway for the redox reactions catalyzed by the enzyme (Figure 1) [7].

Ball (1939) employed pancreatin for the extraction and partial purification of XOR [8]. Apart from degrading the caseins, pancreatin also cleaves XOR, irreversibly changing it to XO. In addition to pancreatin digestion, Gilbert and Bergel (1964) increased the yield through the use of butanol, EDTA and sodium salicylate, but this procedure reduced the final purity of the protein [9]. Waud et al. (1975) later demonstrated that proteolysis actually compromised the purity of the enzyme and they achieved better purification through a combination of butanol extraction, ammonium sulfate precipitation and chromatography [10]. The lowest $\mathrm{A}_{280} / \mathrm{A}_{450}$ value (a measure of protein: flavin) of 4.1 was reported by Zikakis in 1979, together with yields of $21 \%$ which are $110 \%$ higher than any method published before 1979 [8]. To release XOR from its lipoprotein membrane, Zikakis described the use of a mild non-ionic detergent such as Triton X-100, in preference to the harsher lipolytic enzymes or butanol [8]. Nonetheless, studies carried out by Briley and Eisenthal (1975) show that complete dissociation of XOR to yield the free enzyme was better achieved through tryptic digestion [11]. Various chromatographic techniques have been attempted, including calcium phosphate [9], folate affinity [12] [13], Sephadex G-75, Sephacryl S-200, Sephadex G-200 and DEAE Sepharose CL-6B anionic exchange [8]. By 1993, XOR was discovered to have an intrinsic affinity to heparin [14], a property which was later exploited for its purification [15] through the development of heparin columns.

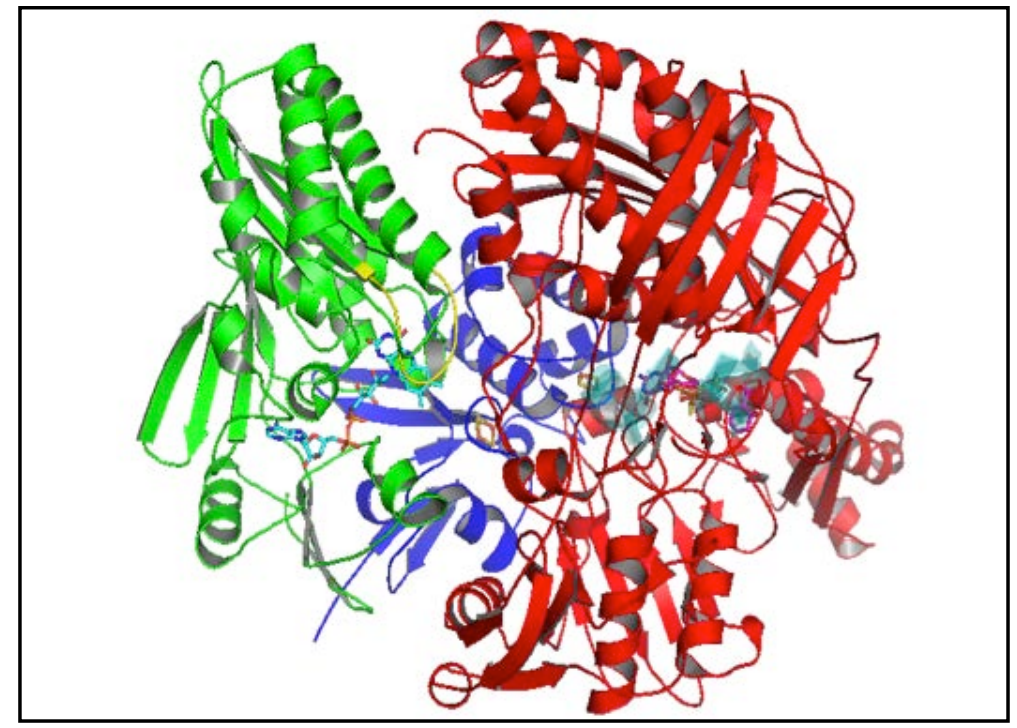

Figure 1. Structure of bovine xanthine oxidoreductase: The monomeric XOR depicting three individual chains corresponding to the FAD domain (green), iron-sulfur cluster domain (blue) and molybdenum domain (red). The biologically active molybdenum cofactor is shown in purple. The salicylate ion, also shown in purple is in proximity of molybdenum cofactor, acting as an active site protector. Two iron-sulfur clusters are depicted in yellow/orange. The yellow loop residing over the FAD cofactor is involved in the $\mathrm{XDH}-\mathrm{XO}$ inter-conversion. Reproduced from PDB entry 1FIQ [7]. 
For more than a century, most of the studies on XOR were conducted on the bovine enzyme. It is only recently that scientists have gained interest in characterizing XOR from the milk of other mammalian sources [16][19]. Human XOR was first isolated, purified and characterized in 1986 from human liver [16]. In 2004, XOR was identified for the first time from both caprine [18] and ovine milk [19] in two independent studies, both of which showed the purified enzyme to be more active than the human XOR but substantially less active than the bovine enzyme [18] [19]. The aim of this study was to extract, purify and characterize XOR from domestic mammals local to the Maltese archipelago.

\section{Materials and Methods}

\subsection{Chemicals}

Unpasteurized bovine, caprine and ovine milk were donated by the Institute of Agribusiness (MCAST, Malta). General purpose chemicals together with cytochrome $c$ from horse heart, trypsin (TPCK treated), Trizma base, NBT and xanthine were supplied by Sigma-Aldrich. Commercial bovine xanthine oxidase, EDTA sodium salt and dithiothreitol were from Roche while 2-N-Morpholinolethane-sulfonic acid, butanol and ammonium sulfate were purchased from VWR. Nicotinamide adenine dinucleotide (oxidised NAD), ECL Western blotting system, HiTrap Heparin HP column and Sephacryl ${ }^{\mathrm{TM}}$ S-200 were from GE Healthcare and HRP-conjugated anti-xanthine oxidase rabbit polyclonal antibody and blocking reagent were from Pierce.

\subsection{Protein Purification from Bovid Milk}

The extraction methodology of bovid XOR is a modification of that reported by Sanders et al. (1997) who described the isolation of XOR from human milk [20]. EDTA, pH 8.0 was added to fresh unpasteurized bovid milk (2 L) to a final concentration of $1 \mathrm{mM}$ and then centrifuged at 3,000 $\mathrm{g}$ for $30 \mathrm{~min}$ at $4^{\circ} \mathrm{C}$. All subsequent purification steps were carried out at $4^{\circ} \mathrm{C}$. The upper cream layer was collected and resuspended in an equal volume of $0.2 \mathrm{M} \mathrm{K}_{2} \mathrm{HPO}_{4}$ containing $1 \mathrm{mM}$ EDTA, stirred for 2 hours, and the centrifugation step repeated. The resultant subnatant was decanted and collected after first perforating the upper solid layer. This subnatant was filtered through glass wool and $15 \% \mathrm{v} / \mathrm{v} n$-butanol (chilled to $-20^{\circ} \mathrm{C}$ prior use) was slowly added to the filtrate whilst stirring. Stirring continued while ammonium sulfate $(15 \% \mathrm{w} / \mathrm{v})$ was added over a $45 \mathrm{~min}$ period. The suspension was centrifuged at 10,000 g for $30 \mathrm{~min}$, the subnatant filtered through glass wool and $20 \% \mathrm{w} / \mathrm{v}$ ammonium sulfate was added over a 30 min period. The mixture was left for a further $45 \mathrm{~min}$ and then centrifuged at 10,000 g for $30 \mathrm{~min}$. The upper "golden” layer was collected, resuspended in an equal volume of $20 \mathrm{mM}$ MES pH 6.5 and dialyzed overnight against $5 \mathrm{~L}$ of the same buffer. The resultant dialysate was centrifuged at 15,000 g for 1 hour and the solution was clarified by filtration through a $0.2 \mu$ mylon syringe filter. A heparin column was equilibrated with $30 \mathrm{~mL}$ of $20 \mathrm{mM}$ MES buffer $\mathrm{pH} 6.5$ and the resuspension applied to the column. It was washed with $50 \mathrm{~mL}$ of $20 \mathrm{mM}$ MES pH 6.5, $0.03 \mathrm{M} \mathrm{NaCl}$ and XOR was eluted using $20 \mathrm{mM} \mathrm{MES,} \mathrm{pH} \mathrm{6.5,} \mathrm{0.4} \mathrm{M} \mathrm{NaCl.}$ The brown elution fractions were dialyzed against $5 \mathrm{~L}$ of $0.01 \mathrm{M}$ sodium phosphate buffer, $\mathrm{pH}$ 7.5. Protein concentration was determined through $\mathrm{A}_{280}$ measurements and the BCA ${ }^{\mathrm{TM}}$ protein assay (Pierce). Protein purity was assessed by $8 \%$ SDS-PAGE and molecular weight was determined by Sephacryl ${ }^{\mathrm{TM}}$ S-200 gel filtration chromatography.

\subsection{Preparation of the Dehydrogenase and Oxidase Forms of Xanthine Oxidoreductase}

Recovery of the XDH form of the enzyme was ensured by the inclusion of $10 \mathrm{mM}$ DTT at each step of the purification process. The xanthine oxidase form was prepared by incubating the XDH fractions collected from the affinity heparin column with $30 \mu \mathrm{g} \cdot \mathrm{mL}^{-1}$ trypsin in $10 \mathrm{mM} \mathrm{Na} \mathrm{PO}_{4}, \mathrm{pH} 7.5$ for 20 hours at $30^{\circ} \mathrm{C}$. DTT and trypsin were both removed from the protein by passing the sample through a second heparin column.

\subsection{Western Blotting}

Pure DTT-treated XDH samples were resolved by 15\% SDS-PAGE and then electroblotted onto nitrocellulose membrane under semi-dry conditions using the LKB Multiphor II with a continuous transfer buffer system (Tris $48 \mathrm{mM}$, glycine $39 \mathrm{mM}$, SDS $0.0375 \% \mathrm{w} / \mathrm{v}$, methanol $20 \% \mathrm{v} / \mathrm{v}$ ) at $0.8 \mathrm{~A} / \mathrm{cm}^{2}$ for 70 minutes. The membrane was blocked overnight with blocking reagent, followed by three washes with freshly prepared TBS-T (TBS + 0.1\% 
TM Tween-20). The primary antibody was diluted 1:10,000 in TBS buffer. XDH protein was visualized by enhanced chemiluminescence.

\subsection{Zymography for Xanthine Oxidase Activity Using 8\% Native PAGE}

The method used was a modification of that described by Zikakis (1979) and the activity stain solution consisted of $10 \mathrm{mM}$ xanthine in $25 \mathrm{mM} \mathrm{NaOH}$ and $15 \mathrm{mM}$ nitroblue tetrazolium (NBT) [8]. Prior to NBT addition, the $\mathrm{pH}$ of the solution was adjusted to 8.3 through the drop-wise addition of $1 \mathrm{M}$ Tris-Cl pH 6.8

\subsection{Spectrophotometric Assays for Xanthine Dehydrogenase Activity}

Pure XOR fractions were assayed for enzyme activity using a DU7500 diode array spectrophotometer, (Beckmann). The assays performed were a modification of the method employed by Sanders et al. (1997). The oxidase activity was measured at $25^{\circ} \mathrm{C}$ by monitoring the production of uric acid at a wavelength of $295 \mathrm{~nm}$ using an absorption coefficient of $9.6 \mathrm{mM} \cdot \mathrm{cm}^{-1}$ [18] [20] [21]. The protein sample $(50 \mu \mathrm{L})$ was added to working solution $(950 \mu \mathrm{L})$ consisting of $100 \mu \mathrm{M}$ xanthine solution in $0.05 \mathrm{M}$ sodium phosphate buffer $\mathrm{pH} 7.5$ using a 10 $\mathrm{mM}$ xanthine in $25 \mathrm{mM} \mathrm{NaOH}$ stock solution. Absorbance readings were recorded at 1-second intervals over a one minute period. The assays were repeated in the presence of $1 \mathrm{mM} \mathrm{NAD}$.

In a separate experiment, XDH samples $(1 \mathrm{~mL})$ were incubated at $4^{\circ} \mathrm{C}$ in the presence of excess FAD and then assayed for activity both in the presence and absence of $\mathrm{NAD}^{+}$. The same samples were also analysed by the cytochrome $c$ assay using a solution of cytochrome $c$ consisting of $60 \mathrm{mg}$ cytochrome $c$ in $350 \mathrm{~mL}$ of potassium phosphate buffer $\mathrm{pH}$ 7.8. This cytochrome $c$ solution $(900 \mu \mathrm{L})$ was mixed with $50 \mu \mathrm{L}$ of xanthine, $\mathrm{NaOH}(10$ mM xanthine, $25 \mathrm{mM} \mathrm{NaOH}$ ) and $50 \mu \mathrm{L}$ of xanthine oxidase sample. Reaction rates were calculated by monitoring the reduction of cytochrome $c$ at a wavelength of $550 \mathrm{~nm}$ at $25^{\circ} \mathrm{C}$, using an absorption coefficient of 21.0 $\mathrm{mM} \cdot \mathrm{cm}^{-1}[21]$.

\section{Results}

\subsection{Enzyme Extraction and Purification}

Purification of xanthine oxidoreductase from three different bovids local to the Maltese archipelago was carried out by standard methods. Bovine milk provided XOR of the highest specific activity and greatest yield while ovine milk gave the least (Table 1). Purified XOR from bovid milk exhibited multiple protein bands when analysed by SDS-PAGE (Figure 2A). The bands corresponding to XOR subunits were identified by immunoblot using an HRP conjugated anti-XOR rabbit polyclonal antibody and confirmed the molecular weights to be of $151.4 \mathrm{kDa}, 131.8 \mathrm{kDa}$ (Figure 2B). An $85.2 \mathrm{kDa}$ fragment and a $64.6 \mathrm{kDa}$ band, the latter present in the commercial bovine XOR sample, also showed a prominent affinity towards the XOR-specific antibody. Fainter bands, having molecular weights of $40.7 \mathrm{kDa}$ and $19.5 \mathrm{kDa}$, present on SDS PAGE were not detected by Western blot.

\subsection{Enzyme Purity and Molecular Weight Determination}

Bovine, caprine and ovine XOR exhibited a protein to flavin ratio (PFR) of 4.88, 6.43 and 5.09 respectively after elution from the Hitrap ${ }^{\mathrm{TM}}$ heparin column. Following gel filtration chromatography, the PFR values recorded were 3.77, 6.27 and 4.52 respectively, reflecting a higher degree of purity. Aside from attaining a higher degree of purity, gel filtration was also used to determine the apparent molecular weight of the native XOR. The results obtained showed the local bovine, caprine and ovine XOR to have apparent molecular weights of $295 \mathrm{kDa}, 281$ $\mathrm{kDa}$ and $275 \mathrm{kDa}$ respectively (Figure 3).

Andrews et al. report the enzyme's molecular weight to be 251 to $321 \mathrm{kDa}$ [22], whereas Cheng et al. determined it to be between 225 and $370 \mathrm{kDa}$ [23]. Most studies carried on bovine XOR state the enzyme's molecular weight as 275 [24], 283 [25] or $290 \mathrm{kDa}$ [7]. XOR from other mammalian sources has been reported as having an apparent molecular weight of $300 \mathrm{kDa}$ [18] [19] [26].

\subsection{Enzyme Activity}

While all samples showed activity when stained on native PAGE (Figure 4), spectrophotometric analysis re- 
Table 1. Purification table for the extraction of Xanthine Oxidoreducctase from bovid milk. Assays were performed without addition of $\mathrm{NAD}^{+}$.

\begin{tabular}{|c|c|c|c|c|c|c|c|}
\hline \multirow[b]{2}{*}{ Purification step } & & \multirow{2}{*}{$\begin{array}{l}\text { Volume } \\
\text { (mL) }\end{array}$} & \multicolumn{2}{|c|}{ Protein } & \multicolumn{2}{|c|}{ Enzyme Activity } & \multirow[b]{2}{*}{ \% Yield } \\
\hline & & & $\begin{array}{l}\text { Concentration } \\
\left(\mathrm{mg} \cdot \mathrm{mL}^{-1}\right)\end{array}$ & Total (mg) & $\begin{array}{l}\text { Specific activity } \\
\left(\text { Units } \mathrm{mg}^{-1} \times 10^{3}\right)\end{array}$ & $\begin{array}{l}\text { Total Activity } \\
\text { (Units) }\end{array}$ & \\
\hline \multirow{3}{*}{ Fresh milk } & Bovine & 1,775 & $26.82 \pm 3.56$ & $47,000.0$ & $1.0 \pm 0.1$ & 47.00 & 100 \\
\hline & Caprine & 2,800 & $23.63 \pm 3.17$ & $66,000.0$ & $0.5 \pm 0.2$ & 35.00 & 100 \\
\hline & Ovine & 2,800 & $50.68 \pm 3.46$ & $142,000.0$ & $0.3 \pm 0.2$ & 42.60 & 100 \\
\hline \multirow{3}{*}{$\begin{array}{l}\text { n-butanol } \\
\text { extraction }\end{array}$} & Bovine & 62 & $6.89 \pm 0.65$ & 427.8 & $26.0 \pm 0.6$ & 11.10 & 24 \\
\hline & Caprine & 222 & $8.24 \pm 0.29$ & 1820.4 & $1.0 \pm 0.4$ & 1.80 & 5 \\
\hline & Ovine & 200 & $12.17 \pm 0.13$ & 2440.0 & $3.0 \pm 0.3$ & 7.30 & 17 \\
\hline \multirow{3}{*}{$\begin{array}{c}\text { Ammonium } \\
\text { sulphate (20\%) }\end{array}$} & Bovine & 11 & $10.14 \pm 0.45$ & 111.1 & $43.0 \pm 2.0$ & 4.78 & 10 \\
\hline & Caprine & 27 & $8.19 \pm 0.50$ & 139.3 & $13.0 \pm 1.0$ & 1.81 & 5 \\
\hline & Ovine & 16 & $7.50 \pm 0.35$ & 120.0 & $4.0 \pm 0.2$ & 0.48 & 11 \\
\hline \multirow{3}{*}{ Heparin column } & Bovine & 5 & $1.45 \pm 0.09$ & 7.2 & $131.0 \pm 6.0$ & 0.94 & 2 \\
\hline & Caprine & 4 & $4.49 \pm 0.21$ & 18.0 & $26.0 \pm 2.0$ & 0.47 & 1 \\
\hline & Ovine & 5 & $3.61 \pm 0.09$ & 18.0 & $6.0 \pm 1.0$ & 0.11 & 0.3 \\
\hline
\end{tabular}
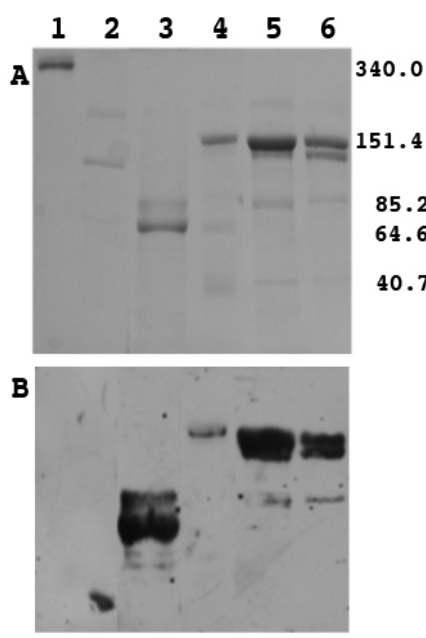

Figure 2. A: 8\% SDS-PAGE: Lane 1: Non-reduced $\alpha$-Macroglobulin, $(3 \mu \mathrm{L}$, $340 \mathrm{kDa})$; Lane 2: Calibration standard proteins (5 $\mu \mathrm{L}, 170,116.4,85.2 \mathrm{kDa})$; Lane 3: Commercial XO (12.5 $\mu \mathrm{g})$; Lanes 4 - 6: Sample from bovine, caprine and ovine milk respectively $(5 \mu \mathrm{L})$. B: Western blot, same gel as in A, using polyclonal anti-XOR antibody.

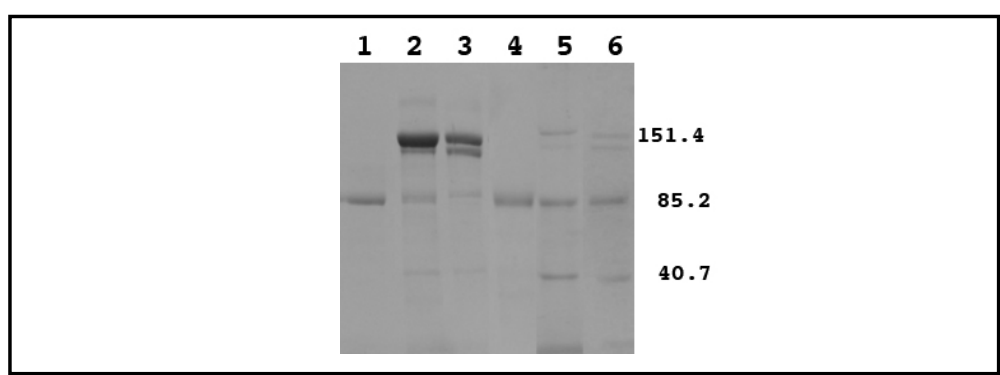

Figure 3. 8\% SDS-PAGE of samples after affinity chromatography (lanes 1 to 3 ) and after gel filtration chromatography (lanes 4 to 6 ). Lanes 1 and 4; bovine, lanes 2 and 5; caprine, lanes 3 and 6; ovine. 


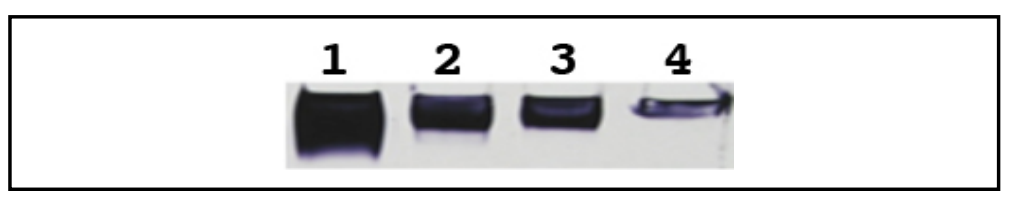

Figure 4. 8\% Native PAGE stained for Xanthine Oxidase activity using NBT. Lane 1: Commercial XO (12.5 ug); Lanes 2 - 4: Samples from bovine, caprine and ovine preparations respectively $(5 \mu \mathrm{L})$.

vealed the bovine XOR to be the most active sample and the ovine the least (Table 2). Each sample was analyzed in the presence and absence of $\mathrm{NAD}^{+}$. $\mathrm{NAD}^{+}$is the preferred electron acceptor of $\mathrm{XDH}$ as opposed to $\mathrm{XO}$ which prefers $\mathrm{O}_{2}$. In the presence of $\mathrm{NAD}^{+}$, both the $\mathrm{XDH}$ and $\mathrm{XO}$ forms are expected to exhibit maximum catalytic activity [18]. However both bovine and caprine enzymes unlike the ovine sample, showed a decrease in uric acid production in the presence of $\mathrm{NAD}^{+}$. The presence of excess FAD did not increase the reaction rate. Once again, the addition of $\mathrm{NAD}^{+}$was inhibitory to the overall reaction rate.

XOR samples were also analyzed for their ability to generate superoxide anions through the cytochrome $c$ assay (Table 3). The change in $A_{550}$ reflected successful reduction of cytochrome $c$ by reactive oxygen species. The bovine XOR showed the highest activity and caprine the least. This is in agreement with the findings of Benboubetra and Baghiani (2004) who reported the ovine XOR to be more active than the caprine XOR, although both are significantly less active than the bovine enzyme.

Following tryptic digest, two major bands were seen on SDS-PAGE corresponding to molecular weights of $85.2 \mathrm{kDa}$ and $72.0 \mathrm{kDa}$. A fainter band of $23.0 \mathrm{kDa}$ was observed in the ovine sample. This pattern of bands was similar to that observed for the commercial bovine XOR (Figure 5), implying that the latter is also subject to proteolytic digestion. The trypsin-treated bovine and ovine enzymes showed a marked increase in oxidase activity, especially the bovine sample whose activity increased nine fold, indicating successful conversion of dehydrogenase to oxidase. Since the presence of FAD did not seem to increase the reaction rate, the observed rise in uric acid production was solely attributed to proteolytic digestion by trypsin.

\section{Discussion}

\subsection{Protein Extraction and Purification}

The extraction and purification of XOR from local bovid milk was achieved through chemical and chromatographic means. Samples from bovine and caprine milk showed a strong binding affinity to an immobilized heparin ligand, whereas ovine XOR did not. XOR has been reported to elute at low salt concentrations only when elution is carried out in the presence of alkaline buffers [14]. Given that all buffers employed in this study had a $\mathrm{pH}$ of 6.5, it appears that the ovine XOR has different chemical properties compared to the bovine and caprine counterparts. There is greater than $94 \%$ homology between the three bovid sequences (Figure 6). One major difference in the known sequences of XOR isolated from these sources is a deletion of 17 amino acids at position 1211 and an insertion of 12 amino acids at position 1266 in the ovine sequence relative to the others (bovine numbering).

Further research on ovine XOR may help to establish the nature of these differences; ovine XOR has only recently been purified [19] and there is very limited data on its structure. The latter would provide data on the relative external distribution of the lysine and arginine residues in the ovine XOR, which are responsible for the affinity of XOR to heparin [14].

Peptide bands corresponding to the subunits of XDH and XO (molecular weights $151.4 \mathrm{kDa}$ and $131.8 \mathrm{kDa}$ ) were observed on SDS-PAGE gels and Western blots. The remaining faint bands, having molecular weights of $85.2 \mathrm{kDa}, 40.7 \mathrm{kDa}$ and $19.5 \mathrm{kDa}$ are likely to be dissociated proteolytic fragments of XOR (Figure 2). Their presence even after gel filtration chromatography makes it unlikely that they are impurities. This is in agreement with the studies of Krentisky, Spector and Hall who report having achieved partial proteolytic fragmentation of the human liver XOR subunits on SDS-PAGE [16]. Cheng et al. (1988) showed that after protease-induced fragmentation, XO was composed of three globular domains, of molecular weight 85 to 100, 30 to 35 and 18 to $20 \mathrm{kDa}$ [23]. Mangino and Brunner (1976), report that degradation of XOR into its subunits also occurs naturally due to endogenous proteases which are present in the milk itself and are co-isolated with XOR during its extraction, which accounts for the fragments obtained in this studies even in the apparent absence of 
Table 2. Specific activity of XOR measured spectrophotometrically at $295 \mathrm{~nm}$, using an absorption coefficient of 9.6 $\mathrm{mM} \cdot \mathrm{cm}^{-1}$. Samples were measured in the absence of additives, with NAD ${ }^{+}$or FAD only or with both NAD ${ }^{+}$and FAD. Each reaction was carried out in triplicate and an average value calculated, to ensure reproducibility. $1 \mathrm{U}$ is defined as the conversion of $1 \mu$ mole of xanthine into $1 \mu$ mole of uric acid per minute at $25^{\circ} \mathrm{C}, \mathrm{pH} 7.5$. All activities are expressed as specific activities; per milligram of enzyme used. ND: not determined.

\begin{tabular}{ccccc}
\hline \multirow{2}{*}{ Sample } & \multicolumn{4}{c}{ Specific activity (Units $\left.\mathrm{mg}^{-1} \times 100\right)$} \\
\cline { 2 - 4 } & Commercial XOR & Bovine XOR & Caprine XOR & Ovine XOR \\
\hline No addition & $77.0 \pm 0.4$ & $13.1 \pm 0.6(125.0 \pm 0.1)$ & $2.6 \pm 0.2$ & $0.6 \pm 0.1(2.7 \pm 0.1)$ \\
$\mathrm{NAD}^{+}$ & $51.4 \pm 0.2$ & $8.5 \pm 0.2$ & $1.3 \pm 0.1$ & $1.1 \pm 0.1$ \\
$\mathrm{FAD}$ & $\mathrm{ND}$ & $12.0 \pm 2.3$ & $1.7 \pm 1.0$ & $0.5 \pm 0.2$ \\
$\mathrm{NAD}^{+} / \mathrm{FAD}$ & $\mathrm{ND}$ & $9.0 \pm 2.7$ & $1.0 \pm 0.3$ & $1.4 \pm 0.1$ \\
\hline
\end{tabular}

Values shown in parenthesis represent enzyme activity after tryptic digest. Purified bovine XOR from a large scale extraction exhibited a specific activity of $104.0 \pm 0.8$.

Table 3. Cytochrome $c$ assay. The reduction of cytochrome $c$ by superoxide anions was monitored at a fixed wavelength of $550 \mathrm{~nm}$, using an extinction coefficient of $21.0 \mathrm{mM} \cdot \mathrm{cm}^{-1}$. This reduction is an indirect measure of XOR activity which produces reactive oxygen species under the reaction conditions used. $1 \mathrm{U}$ is defined as the oxidation of $1 \mu$ mole of reduced cytochrome c per minute at $25^{\circ} \mathrm{C}$. Triplicate readings were recorded for each sample.

\begin{tabular}{ccc}
\hline Sample & A550 $\mathrm{min}^{-1}$ & Specific activity $\left(\mathrm{Units}^{\mathrm{m}} \mathrm{mg}^{-1}\right)$ \\
\hline Commercial bovine XOR & 0.074 & $0.460 \pm 0.002$ \\
Bovine XOR (large scale) & 0.060 & $0.563 \pm 0.003$ \\
Bovine XOR & 0.035 & $0.435 \pm 0.005$ \\
Caprine XOR & 0.054 & $0.003 \pm 0.001$ \\
Ovine XOR & 0.022 & $0.005 \pm 0.002$ \\
\hline
\end{tabular}

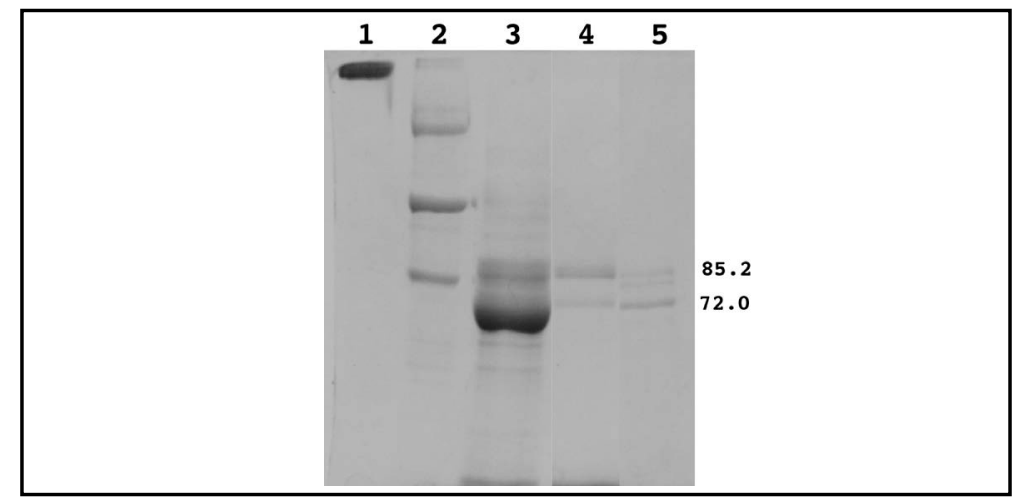

Figure 5. 8\% SDS-PAGE of the tryptic digested samples. Lane 1: Non-reduced $\alpha$-Macroglobulin ( $5 \mu \mathrm{L}, 340 \mathrm{kDa}$ ); Lane 2: Calibration standard proteins (10 $\mu \mathrm{L}, 170,116.4,85.2 \mathrm{kDa})$; Lane 3: Commercial XO (12.5 $\mu \mathrm{g})$; Lane 4: Bovine XO collected during elution (5 $\mu \mathrm{g})$; Lane 5: Ovine XO collected during elution $(5 \mu \mathrm{g})$.

proteolytic enzymes [23] [27]. Despite this, other studies report a single major band (150 kDa) after extraction and purification of XOR from unpasteurized bovine milk [18] [19]. It is likely that this is due to experimental factors including speed of purification away from contaminating proteases.

While proteolysis with trypsin does lead to a loss of the dehydrogenase activity due to structural changes near the FAD cofactor binding site, it has negligible effect on the activity of the oxidase form [19]. This retention of oxidase activity is due to the hydrophobic nature of the resultant peptidyl fragments that remain in close associa- 


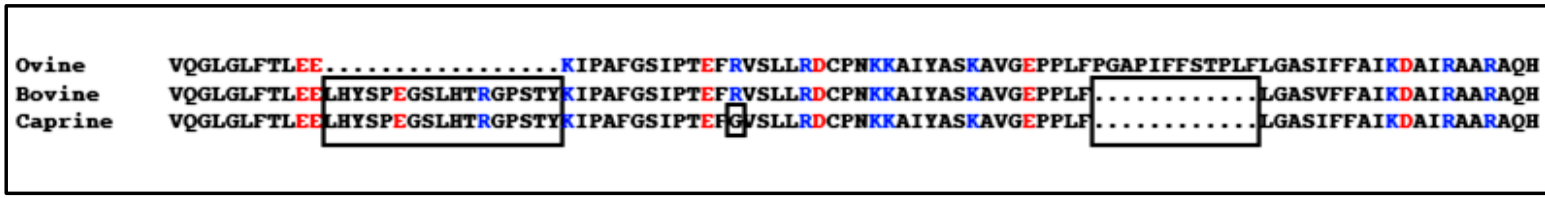

Figure 6. Multiple sequence alignment of Xanthine Dehydrogenases. Ovine (426223865), bovine (27806775) and caprine (119712145) obtained from the NCBI. Red and blue denotes negatively and positively charged residues respectively. Boxes highlight regions that are different from the ovine sequence and include a deletion of 17 amino acids at position 1211 and an insertion of 12 amino acids at position 1266 (ovine numbering).

tion with each other [20]. Indeed, Cheng et al. (1988) report having achieved a single band (151 $\pm 4 \mathrm{kDa}$ ) only on native PAGE electrophoresis [20]. In the absence of SDS, the hydrophobic nature of the enzyme maintains the individual subunits in close proximity to each other even in the presence of proteases, resulting in a slightly broader but single $150 \mathrm{kDa}$ band on a native PAGE [8] [23].

\subsection{Enzyme Activity}

The final product is a mixture of both $\mathrm{XO}$ and $\mathrm{XDH}$. In the absence of a suitable reducing agent, the majority of XOR is normally converted to its oxidase form [20] [28]. In this study, DTT was included during purification, so a high proportion of dehydrogenase was expected to be present in the final sample. Previous studies report that the sum of the oxidase and dehydrogenase activity may be determined by the addition of $\mathrm{NAD}^{+}$to the reaction mixture under aerobic conditions [19]-[21]. The results obtained in this study however, suggest that the reaction is actually inhibited by $\mathrm{NAD}^{+}$in both the bovine and caprine XOR. This is not the case for the ovine XOR. This decrease in reaction rate may be attributed to the production of NADH which is known to compete with $\mathrm{NAD}^{+}$ for the FAD binding site. In the light of this, we postulate that the high proportion of dehydrogenase present in the sample led to a rapid build up of NADH production with consequent XDH inhibition. In the case of the ovine XOR, the addition of $\mathrm{NAD}^{+}$resulted in a two-fold increase in reaction rate. This differential activity exhibited by the ovine XOR may be related to either chemical or structural differences.

An alternative explanation to this differential activity in response to $\mathrm{NAD}^{+}$is due to the effect $\mathrm{NAD}^{+}$has on the rate limiting step of enzyme activity. Kinetic data carried out by Hunt and Massey [21] showed that xanthine oxidation occurs at a higher rate when catalyzed by $\mathrm{XO}$ rather than $\mathrm{XDH}$. As such, the observed decrease in xanthine oxidation in the presence of $\mathrm{NAD}^{+}$can be explained in terms of the lower turnover number of XDH which relies on $\mathrm{NAD}^{+}$as its electron acceptor.

In agreement with literature data, the bovine XOR has the highest rate of xanthine oxidation both in the presence and absence of $\mathrm{NAD}^{+}$. Caprine and ovine XOR showed a considerable lower activity possibly due to lower molybdenum content [18] [19] [29]. Although metal analysis was not part of this investigation, previous experiments report low molybdenum content in caprine and ovine XOR. Moreover it has been shown that activity of caprine and ovine XOR drastically increases after birth [18] [19]. Aside from reinforcing the antibacterial role of XOR in milk, this fact suggests that these mammals might have an intrinsic mechanism to incorporate molybdenum into XOR, so forming a fully functional XOR only when most required [19].

Addition of FAD slightly lowered the xanthine oxidation rate. This small decrease in activity may imply that the presence of excess unbound FAD was impeding enzyme activity, possibly due to alterations in $\mathrm{pH}$. As there was no increase in reaction rate, it is likely that all the XOR enzymes were purified in their fully flavin-bound form. Komai, Massey and Palmer were the first to document the successful reconstitution of the flavoprotein in the presence of FAD and $\left(\mathrm{NH}_{4}\right)_{2} \mathrm{SO}_{4}$ at $25^{\circ} \mathrm{C}$. Nonetheless the same study also reports that unlike other flavoproteins, the flavin prosthetic group of XOR does not usually dissociate under normal purification conditions [30].

Whilst both $\mathrm{XO}$ and $\mathrm{XDH}$ produce uric acid as their final oxidation product, superoxide anions are mostly produced by XO in the absence of NADH. Although kinetic studies show that XDH can potentially produce more superoxide anions than XO via its NADH oxidase activity, in the absence of NADH, its interaction with $\mathrm{O}_{2}$ is very slow, [21] especially if $\mathrm{NAD}^{+}$is present in the mixture. Although no $\mathrm{NAD}^{+}$was added to the cytochrome $c$ assay, the samples analysed were all (except from the commercial XOR) mixtures of both $\mathrm{XO}$ and $\mathrm{XDH}$, the latter being produced as a result of DTT addition during extraction. Consequently, a higher activity reading might not necessarily imply a more reactive enzyme, but possibly a higher proportion of $\mathrm{XO}$ in the sample. 


\subsection{Enzyme Yield}

Bovine, caprine and ovine preparations yielded $18.6 \mathrm{mg}\left(10 \mathrm{mg} \cdot \mathrm{L}^{-1}\right), 18.0 \mathrm{mg}\left(6.8 \mathrm{mg} \cdot \mathrm{L}^{-1}\right)$ and $18.0 \mathrm{mg}(6.18$ $\mathrm{mg} \cdot \mathrm{L}^{-1}$ ) of enzyme respectively. This is similar to the findings reported by Sanders et al. (1997) who documented the recovery of $25 \mathrm{mg}$ enzyme protein from $4 \mathrm{~L}$ of bovine milk, equivalent to $6.25 \mathrm{mg} \cdot \mathrm{L}^{-1}$ [20]. A large scale preparation starting with $6 \mathrm{~L}$ of bovine milk gave a yield of $53 \mathrm{mg}$ of protein which is equivalent to 8.83 $\mathrm{mg} \cdot \mathrm{L}^{-1}$.

\subsection{Conclusion}

XOR was successfully extracted and purified from local unpasteurized bovine, caprine and ovine milk, with the bovine, caprine and ovine preparations yielding $10 \mathrm{mg} \cdot \mathrm{L}^{-1}, 6.8 \mathrm{mg} \cdot \mathrm{L}^{-1}$ and $6.18 \mathrm{mg} \cdot \mathrm{L}^{-1}$ of active enzyme respectively. The dissociation of XOR from its membrane was achieved through butanol addition, without the involvement of proteolytic enzymes. Purified enzyme appeared as five major bands on SDS-PAGE of which only the first three fragments corresponding to molecular weights of $151.4 \mathrm{kDa}, 131.8 \mathrm{kDa}$ and $85.2 \mathrm{kDa}$ were visible on a Western blot. All samples showed XOR activity when stained on native PAGE. Spectrophotometric analysis revealed the bovine enzyme to be the most active both in the presence and absence of $\mathrm{NAD}^{+}$, followed by the caprine and then ovine sample. The addition of $\mathrm{NAD}^{+}$to the assay mixture was inhibitory and reduced the rate of uric acid production in the case of the bovine and caprine samples. Bovine XOR showed a nine fold increase in oxidase activity following tryptic digestion. No increase in the reaction rate was observed with the addition of excess FAD. When carried out on a large scale starting with $6 \mathrm{~L}$ of bovine milk, the extracted XOR showed an activity superior to the commercial bovine XOR for both spectrophotometric assays.

\section{Acknowledgements}

We wish to thank Mr. and Ms. G. Camilleri, Mr. C. Zahra and the staff at the Institute of Agribusiness for kindly donating fresh samples of milk. This work was funded by research fund MDSIN08-20 to GJH.

\section{References}

[1] Hille, R. and Nishino, T. (1995) Xanthine Oxidase and Xanthine Dehydrogenase. The FASEB Journal, 9, $995-1003$.

[2] Okamoto, K., Matsumoto, K., Hille, R., Eger, B.T., Pai, E.F. and Nishino, T. (2004) The Crystal Structure of Xanthine Oxidoreductase during Catalysis: Implications for Reaction Mechanism and Enzyme Inhibition. PNAS, 101, 7931-7936. http://dx.doi.org/10.1073/pnas.0400973101

[3] Vorbach, C., Harrison, R. and Capecchi, M.R. (2003) Xanthine Oxidoreductase is Central to the Evolution and Function of the Innate Immune System. Immunology, 24, 512-517.

[4] Steven, C.R., Millar, T.M., Clinach, J.G., Kanczier, K.M., Bodamyall, T. and Blake, D.R. (2000) Antibacterial Properties of Xanthine Oxidase in Human Milk. Lancet, 356, 829. http://dx.doi.org/10.1016/S0140-6736(00)02660-X

[5] Hancock, J.T., Salisbury, V., Ovejero-Boglione, M.C., Cherry, R., Hoare, C., Eisenthal, R. and Harrison, R. (2002) Antimicrobial Properties of Milk: Dependence on Presence of Xanthine Oxidase and Nitrite. Antimicrobial Agents and Chemotherapy, 46, 3308-3310. http://dx.doi.org/10.1128/AAC.46.10.3308-3310.2002

[6] Scopes, R.K. (1987) Protein Purification: Principles and Practice. 2nd Edition, Springer-Verlag, New York, 41-64.

[7] Enroth, C., Eger, B.T., Okamoto, K., Nishino, T., Nishino, T. and Pai, E.F. (2000) Crystal Structures of Bovine Milk Xanthine Dehydrogenase and Xanthine Oxidase: Structure based Mechanism of Conversion. PNAS, 97, 10723-10728. http://dx.doi.org/10.1073/pnas.97.20.10723

[8] Zikakis, J. (1979) Preparation of High Purity Xanthine Oxidase from Bovine Milk. U.S. Patent No. 806,736.

[9] Gilbert, D.A. and Bergel, F. (1964) The Chemistry of Xanthine Oxidase: An Improved Method of Preparing the Bovine Milk Enzyme. Biochemical Journal, 90, 350-353.

[10] Waud, W.R., Brady, F.O., Wiley, R.D. and Rajagopalan, K.V. (1975) A New Purification Procedure for Bovine Milk Xanthine Oxidase: Effect of Proteolysis on the Subunit Structure. Archives of Biochemistry and Biophysics, 169, 695701. http://dx.doi.org/10.1016/0003-9861(75)90214-3

[11] Briley, M.S. and Eisenthal, R. (1975) Association of Xanthine Oxidase with the Bovine Milk-Fat-Globule Membrane: Nature of the Enzyme-Membrane Association. Biochemical Journal, 147, 417-423.

[12] Nishino, T., Nishino, T. and Tsushima, K. (1981) Purification of Highly Active Milk Xanthine Oxidase by Affinity Chromatography on Sepharose 4B/Folate Gel. The FASEB Journal, 131, 369-372. 
http://dx.doi.org/10.1016/0014-5793(81)80406-1

[13] Nishino, T. and Tsushima, K. (1986) Interaction of Milk Xanthine Oxidase with Folic Acid. Inhibition of Milk Xanthine Oxidase by Folic Acid and Separation of the Enzyme into Two Fractions on Sepharose 4B/Folate Gel. The Journal of Biological Chemistry, 261, 11242-11246.

[14] Fukushima, T., Adachi, T. and Hirano, K. (1995) The Heparin Binding Site of Human Xanthine Oxidase. Biological \& Pharmaceutical Bulletin, 84, 156-158. http://dx.doi.org/10.1248/bpb.18.156

[15] Nishino, T., Okamoto, K., Eger, B.T., Pai, E.F. and Nishino, T. (2008) Mammalian Xanthine Oxidoreductase- Mechanism of Transition from Xanthine Dehydrogenase to Xanthine Oxidase. The FASEB Journal, 275, 3278-3289. http://dx.doi.org/10.1111/j.1742-4658.2008.06489.x

[16] Krenitsky, T.A., Spector, T. and Hall, W.W. (1986) Xanthine Oxidase from Human Liver: Purification and Characterisation. Archives of Biochemistry and Biophysicss, 247, 108-119. http://dx.doi.org/10.1016/0003-9861(86)90539-4

[17] Moriwaki, Y., Yamamoto, T., Suda, Nasako, Y., Takahashi, S., Agbedana, O., Hada, T. and Higashino, K. (1993) Purification and Immunohistochemical Tissue Localisation of Human Xanthine Oxidase. Biochimica et Biophysica Acta, 1164, 327-330. http://dx.doi.org/10.1016/0167-4838(93)90266-T

[18] Atmani, D., Benboubetra, M. and Harrison, R. (2003) Goa’s Milk Xanthine Oxidoreductase Is Grossly Deficient in Molybdenum. Journal of Dairy Science, 71, 7-13.

[19] Benboubetra, M., Baghiani, A., Atmani, D. and Harrison, R. (2004) Physiochemical and Kinetic Properties of Purified Sheep’s Milk Xanthine Oxidoreductase. Journal of Dairy Science, 87, 1580-1584. http://dx.doi.org/10.3168/jds.S0022-0302(04)73311-1

[20] Sanders, S.A., Eisenthal, R. and Harrison, R. (1997) NADH Oxidase Activity of Human Xanthine Oxidoreductase: Generation of Superoxide Anion. European Journal of Biochemistry, 245, 541-548. http://dx.doi.org/10.1111/j.1432-1033.1997.00541.x

[21] Hunt, J. and Massey, V. (1992) Purification and Properties of Milk Xanthine Dehydrogenase. The Journal of Biological Chemistry, 267, 21479-21485.

[22] Andrews, P., Bray, R.C., Edwards, P. and Shooter, K.V. (1964) The Chemistry of Xanthine Oxidase: Ultracentrifuge and Gel-Filtration Studies on the Milk Enzyme. Biochemical Journal, 93, 627-632.

[23] Cheng, S.G., Koch, U. and Brunner, R. (1988) Characteristics of Purified Cows’ Milk Xanthine Oxidase and its Submolecular Characterisitics. Journal of Dairy Science, 71, 901-916. http://dx.doi.org/10.3168/jds.S0022-0302(88)79636-8

[24] Hart, L.I., McGartoll, M.A., Chapman, H.R. and Bray, R.C.R. (1970) The Composition of Milk Xanthine Oxidase. Biochemical Journal, 116, 851-864.

[25] Bray, R.C. (1975) The Enzymes. 3rd Edition, B, Academic Press, New York, 303-388.

[26] Carpani, G., Racchi, M., Ghezzi, P., Terao, M. and Garattini, E. (1990) Purification and Characterization of Mouse Liver Xanthine Oxidase. Archives of Biochemistry and Biophysics, 279, 237-241. http://dx.doi.org/10.1016/0003-9861(90)90487-J

[27] Mangino, M.E. and Brunner, J.R. (1997) Isolation and Partial Characterization of Xanthine Oxidase Associated with the Milk Fat Globule Membrane of Cow’s Milk. Journal of Dairy Science, 60, 841-850. http://dx.doi.org/10.3168/jds.S0022-0302(77)83952-0

[28] McManaman, J.L. and Bain, D.L. (2002) Structural and Conformational Analysis of the Oxidase to Dehydrogenase Conversion of Xanthine Oxidoreductase. The Journal of Biological Chemistry, 277, 21261-21268. http://dx.doi.org/10.1074/jbc.M200828200

[29] Guskov, E.P., Kletskii, M.E., Kornienko, I.V., Olekhnovich, L.P., Chistyakov, V.A., Shkurat, T.P., Prokofev, V.N. and Zhdanov, Y. (2002) Allantoin as a Free Radical Scavenger. Archives of Biochemistry and Biophysics, 383, 105-107.

[30] Komai, H., Massey V. and Palmer, G. (1968) The Preparation and Properties of Deflavo Xanthine Oxidase. The Journal of Biochemistry, 244, 1692-1700. 